\title{
Impact of Irradiation and Immunoglobulin G Concentration on Absorption of Protein and Immunoglobulin G in Calves Fed Colostrum Replacer
}

\author{
J. M. Campbell, ${ }^{\star 1}$ L. E. Russell, ${ }^{\star}$ J. D. Crenshaw, ${ }^{\star}$ E. M. Weaver, ${ }^{\star}$ S. Godden, $†$ J. D. Quigley,ł \\ J. Coverdale,§ and $\mathrm{H}$. Tyler\| \\ ${ }^{*}$ APC Inc., Ankeny, IA 50021 \\ †Department of Veterinary Population Medicine, University of Minnesota, St. Paul 55108 \\ fDiamond V Mills, Cedar Rapids, IA 52407 \\ $\S$ Department of Animal Science, Texas A\&M University, College Station 77843 \\ |Department of Animal Science, lowa State University, Ames 50011
}

\begin{abstract}
The objective of this study was first to evaluate whether irradiation treatment of a commercial colostrum replacer (CR) affected acquisition of passive immunity. If the irradiation treatment negatively affected the acquisition of passive immunity, the second objective was to evaluate whether an increased total IgG mass, in a single feeding of CR derived from bovine serum fractions, could compensate for this effect. Acquisition of passive immunity was assessed by 24 -h serum IgG levels, serum protein levels, apparent efficiency of absorption (AEA) of IgG, and the ability to prevent failure of passive transfer (FPT) in day-old dairy calves fed a single feeding of CR. Single-dose packs of CR were sent to a commercial irradiation facility for electronbeam irradiation at 3 to $7 \mathrm{kGy}$ (low irradiation) or 15 to $20 \mathrm{kGy}$ (high irradiation). Fifty-six Holstein, Jersey, or crossbred calves were randomly assigned to 1 of 5 treatments: 1) $130 \mathrm{~g}$ of $\operatorname{IgG}(460 \mathrm{~g}$ of CR), no irradiation; 2) $130 \mathrm{~g}$ of $\mathrm{IgG}$ (460 g of CR), low irradiation; 3) $160 \mathrm{~g}$ of IgG (518 g of CR), low irradiation; 4) $190 \mathrm{~g}$ of IgG (575.4 $\mathrm{g}$ of CR), low irradiation; and 5) $130 \mathrm{~g}$ of IgG (460 $\mathrm{g}$ of $\mathrm{CR}$ ), high irradiation. All CR were reconstituted in water and mixed in a household blender to a constant solids concentration of $18.7 \%$. Increasing doses of irradiation (130 g of Ig with no, low, or high irradiation) resulted in a linear decrease in 24-h serum IgG and AEA of IgG, and increased the percentage of calves with FPT. Increasing the IgG mass in the CR $(130,160$, and $190 \mathrm{~g}$ of $\mathrm{Ig}$ with low irradiation) resulted in a linear increase in 24-h serum IgG and serum total protein levels, and a linear decrease in AEA of IgG. There was no effect of increasing the mass of IgG fed on the per-
\end{abstract}

Received February 28, 2007.

Accepted September 7, 2007.

${ }^{1}$ Corresponding author: joy.campbell@amerprotcorp.com centage of calves with FPT. The correlation between serum IgG and serum total protein at $24 \mathrm{~h}$ was positive; however, at $24 \mathrm{~h}$ the irradiation treatments reduced the serum IgG-to-serum total protein ratio. In this study, CR isolated from bovine serum, providing 130 $\mathrm{g}$ of IgG in the first feeding and receiving either no irradiation or a low irradiation treatment, was sufficient to prevent FPT in calves.

Key words: calf, immunoglobulin, colostrum replacer, irradiation

\section{INTRODUCTION}

Calf health and survival affect the economics of a dairy operation. Feeding a sufficient quantity of highquality colostrum within the first few hours of birth plays a vital role in calf health, survival, and subsequent performance (Robison et al., 1988; DeNise et al., 1989; Wittum and Perino, 1995; Faber et al., 2005). Failure of passive transfer (FPT) is generally defined as serum IgG levels of $<10 \mathrm{~g} / \mathrm{L}$ in calves at $24 \mathrm{~h}$ of age (Bovine Alliance on Management and Nutrition, 1995; Davis and Drackley, 1998). A number of factors have been identified that influence IgG absorption by the young calf, including the quantity and quality of colostrum, time of first feeding, metabolic status of the calf, and colostrum management practices (Stott et al., 1979a,b; Garry et al., 1996; Morin et al., 1997; Quigley et al., 1998, 2001). Calves with FPT are more likely to die or become chronically ill, which increases medical costs and requires additional labor (Robison et al., 1988; National Animal Health Monitoring System, 1993; Donovan et al., 1998). In addition, fresh maternal colostrum can be contaminated with pathogens (Salmonella spp., Mycobacterium paratuberculosis, Escherichia coli, Mycoplasma bovis mastitis, Staphylococcus aureus mastitis, bovine viral diarrhea virus, and bovine leukemia virus), resulting in increased risk of disease transmission (McGuirk and Collins, 2004). 
Protein fractions isolated from bovine serum high in $\operatorname{IgG}(\sim 50 \% \operatorname{IgG})$, blended with other nutrients and fed to calves, have been shown to prevent FPT (Quigley et al., 2001; Hammer et al., 2004; Jones et al., 2004). Time of feeding, IgG mass, and total nutrient mass have been shown to affect apparent efficiency of absorption (AEA) of IgG (Quigley et al., 2001; Hammer et al., 2004). Combined use of commercially available bovine serumbased products providing 125 and $50 \mathrm{~g}$ of IgG fed at 1 and $6 \mathrm{~h}$ after birth, respectively, have been shown to be as effective as high-quality maternal colostrum in preventing FPT (Poulsen et al., 2003). However, Swan et al. (2007) reported that $93 \%$ of calves experienced FPT when fed $125 \mathrm{~g}$ of IgG from a commercially available colostrum replacer (CR). The optimal mass of IgG derived from bovine serum protein fractions necessary to consistently prevent FPT has not been reported.

Irradiation effectively reduces microbial contamination (Carpenter, 1963). Bender et al. (1989) reported that mycoplasma in calf serum is inactivated when irradiated with $3 \mathrm{kGy}$ of gamma irradiation. However, irradiation has also been shown to reduce vitamin levels, oxidize fat, and alter protein structure (El-Moneim et al., 1988; Leeson and Marcotte, 1993). Tran et al. (2004) reported negligible changes in IgG structure after treatment of an Ig-rich paste with a virucidal dose of irradiation (50 kGy). The effects of irradiation treatment on AEA of IgG from bovine serum protein fractions are unknown.

Therefore, the objectives of this study were first, to evaluate whether irradiation treatment of a commercial CR derived from bovine serum fractions affected acquisition of passive immunity. Second, if irradiation treatment negatively affected acquisition of passive immunity, whether increased total IgG mass in a single feeding could compensate for this effect. Acquisition of passive immunity was assessed by 24 -h serum IgG levels, serum protein levels, AEA, and the ability to prevent FPT in day-old dairy calves fed a single feeding.

\section{MATERIALS AND METHODS}

\section{Animals and Treatments}

Bovine blood was collected from animals slaughtered at a USDA-inspected abattoir into a stainless-steel container containing anticoagulant. Plasma was separated by centrifugation, chilled (approximately $4^{\circ} \mathrm{C}$ ), and transported to a commercial facility for further processing by centrifugation, ultrafiltration, and spraydrying to produce an IgG concentrate. The IgG concentrate contained $>90 \% \mathrm{CP}$ and $>50 \%$ IgG and was mixed with other ingredients (carbohydrate, fat, vitamins, and minerals) to produce a CR packaged in single-dose units
Table 1. Calculated chemical analysis of colostrum replacers (as-fed basis)

\begin{tabular}{lccc}
\hline & \multicolumn{3}{c}{ Colostrum replacer } \\
\cline { 2 - 4 } Item & 130 g of IgG & 160 g of IgG & 190 g of IgG \\
\hline IgG, \% & 28.3 & 30.9 & 33.0 \\
CP, \% & 50.8 & 55.2 & 58.7 \\
Fat, \% & 15.2 & 13.5 & 12.1 \\
Ca, \% & 0.99 & 0.89 & 0.82 \\
P, \% & 0.94 & 0.92 & 0.89 \\
Vitamin A, IU/g & 109.0 & 96.5 & 86.9 \\
Vitamin D, IU/g & 21.7 & 19.3 & 17.4 \\
Vitamin E, IU/g & 0.33 & 0.29 & 0.26 \\
\hline
\end{tabular}

(Table 1). When irradiated, single-dose packs of CR were sent to a commercial irradiation facility (Sadex Corporation, Sioux City, IA) and treated with electronbeam (e-beam) irradiation at 3 to $7 \mathrm{kGy}$ (low irradiation; L) or 15 to $20 \mathrm{kGy}$ (high irradiation; $\mathbf{H}$ ).

Fifty-six Holstein, Jersey, or crossbred bull calves on a large California dairy were used. Breeds were randomly distributed across treatments. Calves were immediately removed from their dams at birth $(<5 \mathrm{~min}$ after birth) and moved to a calf housing area, where they were weighed, identified by individual number, navel dipped, fitted with an elastic castrator, and placed in elevated individual stalls fitted with a heat lamp. Calves were randomly assigned to 1 of 5 treatments: 1) $130 \mathrm{~g}$ of IgG (460 g of CR), no irradiation (130NR); 2) $130 \mathrm{~g}$ of IgG (460 g of CR), low irradiation (130L); 3) $160 \mathrm{~g}$ of IgG (518 g of CR), low irradiation (160L); 4) $190 \mathrm{~g}$ of IgG (575.4 g of CR), low irradiation (190L); and 5) $130 \mathrm{~g}$ of $\operatorname{IgG}(460 \mathrm{~g}$ of $\mathrm{CR})$, high irradiation (130H). Colostrum replacers containing $130 \mathrm{~g}$ of $\mathrm{IgG}$ mass were treated with zero, low, or high levels of irradiation to determine whether irradiation treatments affected acquisition of passive immunity. Colostrum replacers treated with low irradiation were formulated to provide 130,160 , or $190 \mathrm{~g}$ of IgG mass to determine the amount of IgG mass required to achieve passive immunity, with the presumption that irradiation may adversely affect passive immunity. The CR providing $130 \mathrm{~g}$ of IgG and treated with low irradiation was a common treatment in both titrations. All CR were reconstituted in water $\left(41^{\circ} \mathrm{C}\right)$ and mixed in a household blender to a solids concentration of $18.7 \%$. Treatments were administered at $1 \mathrm{~h}$ of age with an esophageal feeder, followed by a second feeding of $1.9 \mathrm{~L}$ of commercial milk replacer ( $18 \%$ protein, $20 \%$ fat) at $12 \mathrm{~h}$ of age.

At 0.5 and $24 \mathrm{~h}$ of age, blood samples were collected from all calves via jugular venipuncture into evacuated red-topped tubes. Serum was collected following centrifugation and frozen $\left(-20^{\circ} \mathrm{C}\right)$ for subsequent analysis of serum total protein and IgG levels. 
Table 2. Means of treatment parameters for calves fed colostrum replacers containing graded levels of IgG concentration processed with no, low, or high irradiation

\begin{tabular}{|c|c|c|c|c|c|c|c|c|}
\hline \multirow[b]{2}{*}{ Item } & \multicolumn{5}{|c|}{ Treatment $^{1}$} & \multirow[b]{2}{*}{ SEM } & \multicolumn{2}{|c|}{$\operatorname{Contrasts}^{2}(P=)$} \\
\hline & $130 \mathrm{NR}$ & $130 \mathrm{~L}$ & $130 \mathrm{H}$ & $160 \mathrm{~L}$ & $190 \mathrm{~L}$ & & 1 & 2 \\
\hline Calves, no. & 11 & 11 & 11 & 11 & 12 & & & \\
\hline Birth BW, kg & 37.3 & 35.6 & 37.0 & 38.6 & 35.6 & & & \\
\hline IgG intake, $g$ & 130 & 130 & 130 & 160 & 190 & & & \\
\hline \multicolumn{9}{|l|}{ Serum $\operatorname{IgG},{ }^{3} \mathrm{~g} / \mathrm{L}$} \\
\hline $0 \mathrm{~h}$ & 0.4 & 0.2 & 0.3 & 0.6 & 0.7 & 0.2 & 0.6987 & 0.1174 \\
\hline $24 \mathrm{~h}$ & 13.0 & 11.6 & 9.7 & 13.3 & 14.3 & 0.8 & 0.0053 & 0.0164 \\
\hline Change 0 to $24 \mathrm{~h}$ & 12.5 & 11.4 & 9.4 & 12.7 & 13.6 & 0.8 & 0.0060 & 0.0452 \\
\hline \multicolumn{9}{|l|}{ Serum total protein, ${ }^{3} \mathrm{~g} / \mathrm{dL}$} \\
\hline $0 \mathrm{~h}$ & 4.0 & 3.9 & 3.8 & 4.0 & 3.9 & 0.1 & 0.3817 & 0.7832 \\
\hline $24 \mathrm{~h}$ & 4.9 & 4.8 & 4.5 & 5.0 & 5.1 & 0.1 & 0.0638 & 0.0860 \\
\hline Change 0 to $24 \mathrm{~h}$ & 0.9 & 0.8 & 0.7 & 1.0 & 1.1 & 0.1 & 0.2015 & 0.1118 \\
\hline $\mathrm{AEA}, 4 \%$ & 34.3 & 31.5 & 25.8 & 29.8 & 26.6 & 1.8 & 0.0015 & 0.0562 \\
\hline Failure of passive transfer, $\%$ & 18.2 & 18.2 & 54.6 & 9.1 & 8.3 & 11.8 & 0.0193 & 0.5496 \\
\hline IgG:protein ratio ${ }^{3} \mathrm{mg} / \mathrm{g}$ & 259.4 & 242.7 & 210.6 & 262.9 & 279.3 & 12.3 & 0.0063 & 0.0358 \\
\hline
\end{tabular}

\footnotetext{
${ }^{1}$ Treatments: $130 \mathrm{NR}=130 \mathrm{~g}$ of IgG with no irradiation; $130 \mathrm{~L}=130 \mathrm{~g}$ of IgG with low irradiation; $160 \mathrm{~L}=$ $160 \mathrm{~g}$ of IgG with low irradiation; 190L = $190 \mathrm{~g}$ of IgG with low irradiation; and $130 \mathrm{H}=130 \mathrm{~g}$ of IgG with high irradiation.

${ }^{2}$ Contrast: 1 = linear effect of irradiation dose with $130 \mathrm{~g}$ of IgG; 2 = linear effect of IgG mass with a low dose of irradiation.

${ }^{3}$ Least squares means adjusted by BW as a covariate.

${ }^{4}$ Apparent efficiency of IgG absorption, calculated as serum IgG at $24 \mathrm{~h} \times \mathrm{BW}$ at birth, $\mathrm{kg} \times 0.09$ (serum volume as a percentage of BW), divided by IgG intake (g).
}

\section{Analytical Procedures}

Serum total protein was determined by the biuret method (Pointe Scientific Inc., Canton, MI). Immunoglobulin $\mathrm{G}$ was determined by a commercially available radial immunodiffusion kit (Triple J Farms, Redmond, WA).

\section{Statistical Analysis}

Experimental data were analyzed as a completely randomized design by ANOVA, using PROC GLM of SAS (SAS Institute, Cary, NC; Table 2). Independent variables consisted of treatment, with $\mathrm{BW}$ as a covariate when appropriate. Dependent variables were serum total protein and IgG at 0 and $24 \mathrm{~h}$ and the change from 0 to $24 \mathrm{~h}, \mathrm{AEA}$, and the IgG-to-protein ratio. Body weight at birth was used as a covariate in the model of serum total protein and serum IgG ( 0 and $24 \mathrm{~h}$ ) to account for breed differences. When BW at birth was included as a covariate, it explained a significant amount of variation in the model $(P<0.05)$; thus, least squares means are reported for serum total protein and serum IgG. Unadjusted means are reported for all other data. The percentage of calves with FPT was analyzed by chi-squared analysis (SAS Institute). Preplanned nonorthogonal contrasts were used to make treatment comparisons. Contrast one was the linear effect of irradiation treatment, which included treatments 130NR, $130 \mathrm{~L}$, and $130 \mathrm{H}$, and contrast two was the linear effect of IgG mass, which included treatments 130L, 160L, and 190L. Linear contrast statements were used to produce the respective contrast; however, for unequally spaced treatments (irradiation treatments) PROC IML (SAS Institute) was used to produce appropriate coefficients for linear contrast statements. Simple regression analysis was used to explain the serum IgG-to-protein relationship attributed to either IgG concentration or irradiation (Figures 1 and 2). Significant values are stated within the text.

\section{RESULTS AND DISCUSSION}

Commercial irradiation is used to reduce microbial contamination of feed ingredients or finished products. Several studies have shown that up to $60 \mathrm{kGy}$ of gamma irradiation will reduce bacterial concentrations without damaging protein quality (Metta and Johnson, 1959; Carpenter, 1963; Farag, 1998). Ford (1976) reported no differences in protein quality of rat diets treated with gamma irradiation up to $100 \mathrm{kGy}$. DeRouchey et al. (2003) reported that irradiation of spray-dried plasma (8.5 kGy from e-beam) used in pig starter feeds resulted in an improved rate and efficiency of growth, whereas irradiation of the complete feed containing spray-dried plasma did not improve nursery pig performance. Additionally, Tran et al. (2004) reported that intravenous Ig preparations could be treated with $50 \mathrm{kGy}$ of gamma irradiation without causing damage to the IgG mole- 


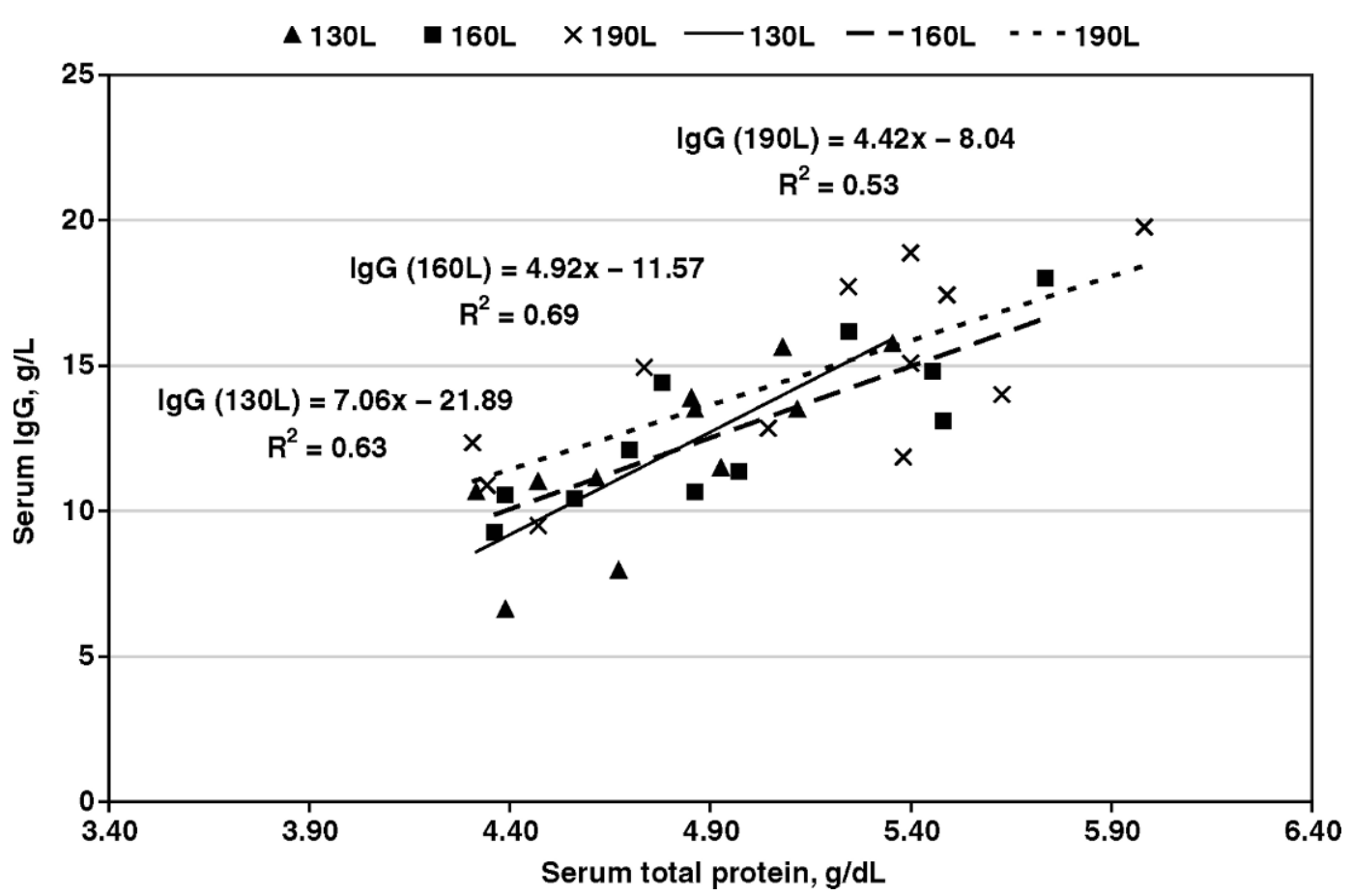

Figure 1. Regression of serum IgG and serum total protein at $24 \mathrm{~h}$ of age from calves fed a colostrum replacer irradiated with a low dose (3 to $7 \mathrm{kGy})$ of irradiation and containing $130(\mathbf{\Delta}), 160(\mathbf{\square})$, or $190(\times) \mathrm{g}$ of IgG/dose.

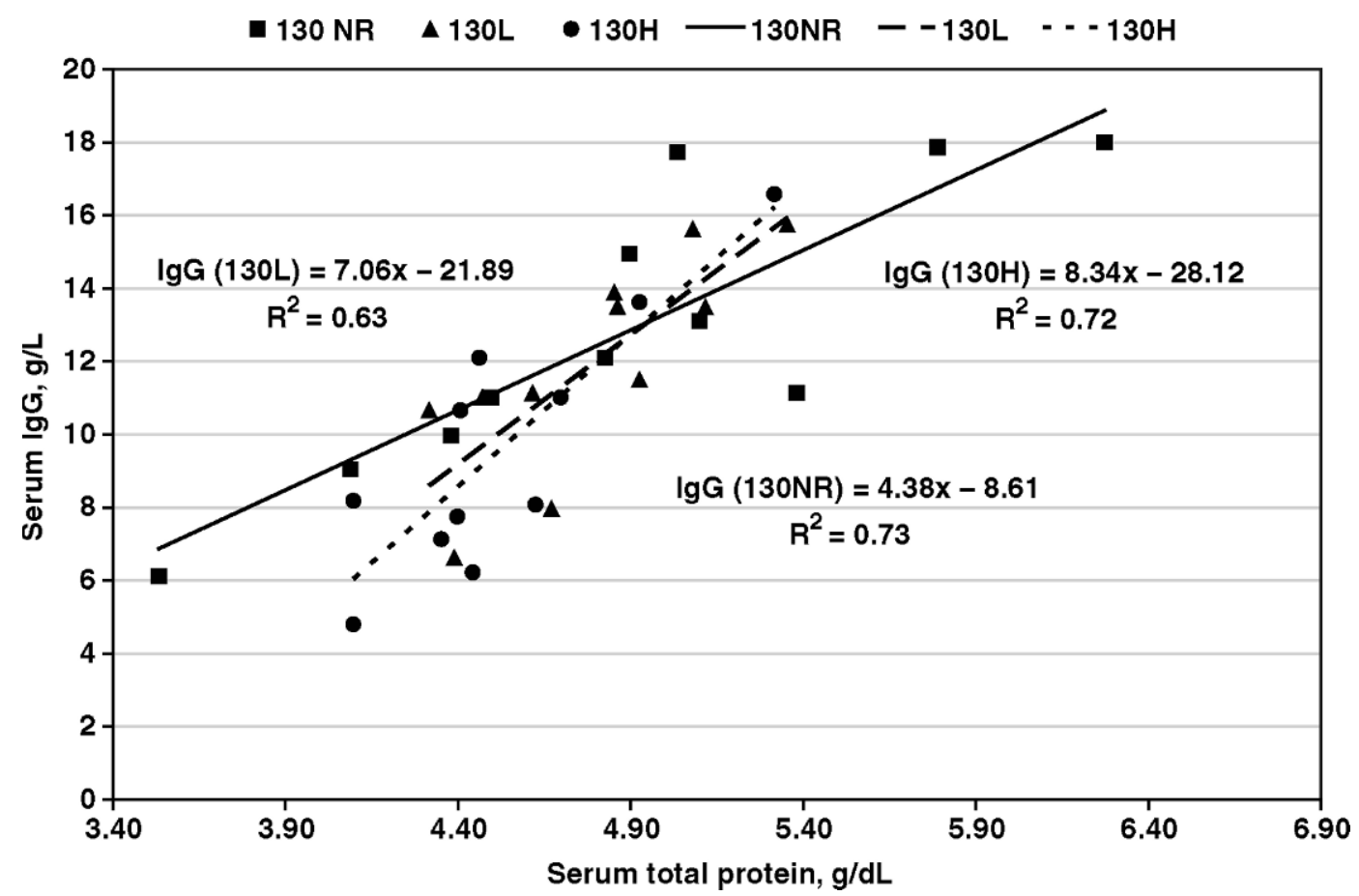

Figure 2. Regression of serum IgG and serum total protein at $24 \mathrm{~h}$ of age from calves fed a colostrum replacer containing $130 \mathrm{~g}$ of IgG/ dose and treated with no (0 kGy; $\mathbf{0})$, low (3 to $7 \mathrm{kGy}$; L; $\mathbf{\Delta})$, or high (15 to $20 \mathrm{kGy}$; H; $)$ irradiation. 
cule. Leeson and Marcotte (1993) reported no effects on dietary nutrient composition of feed, growth rate, or feed efficiency of poultry when feed was irradiated up to $25 \mathrm{kGy}$, whereas increasing irradiation greater than $25 \mathrm{kGy}$ resulted in reduced potency of vitamins A and D. In the current study, a commercial irradiation facility was used to irradiate the treatments. Commercial facilities have limitations on dosing ranges because of the density of the material being irradiated. Based on the density of the CR, the irradiation dose was selected to minimize the range applied while still being able to irradiate treatments as commercially packaged, with density similar to the finished product. In this trial, increasing e-beam irradiation to a high of 15 to $20 \mathrm{kGy}$ resulted in a linear decrease $(P<0.01)$ in 24 -h serum IgG and AEA of IgG (Table 2). More than $50 \%$ of the calves fed the CR irradiated with the high irradiation dose experienced FPT. Similar to the level reported by Bender et al. (1989) to inactivate mycoplasma, the low irradiation dose (3 to $7 \mathrm{kGy}$ ) had a minimal effect on the AEA of IgG and the percentage of calves experiencing FPT compared with calves fed CR that was not irradiated (130NR).

Increasing the IgG mass in the CR $(130 \mathrm{~L}, 160 \mathrm{~L}$, and $190 \mathrm{~L})$ resulted in a linear increase in 24 -h serum IgG $(P<0.02)$ and serum total protein levels $(P<0.09)$, and a linear decrease in the AEA of IgG $(P<0.06$; Table 2$)$. There was no effect $(P>0.10)$ of increasing the mass of IgG being fed on the percentage of calves experiencing FPT (18.2, 9.1, and 8.3\%, respectively). These data are consistent with other reports indicating that feeding calves between 100 and $250 \mathrm{~g}$ of bovine serum-derived IgG was sufficient to prevent FPT in 82 to $100 \%$ of the calves (Quigley et al., 2001; Hammer et al., 2004; Jones et al., 2004). However, Swan et al. (2007) recently reported a high incidence of FPT in calves fed bovine serum-based CR. Results of the current study indicated that $130 \mathrm{~g}$ of IgG isolated from bovine serum and treated with either a low dose or no irradiation was sufficient to prevent FPT in more than $80 \%$ of the calves receiving $\mathrm{CR}$, whereas a higher irradiation dose resulted in more than $50 \%$ of the calves experiencing FPT. Increasing the mass of IgG increased the average 24-h serum IgG and serum total protein levels, but did not further reduce the incidence of FPT.

Twenty-four-hour serum total protein and serum IgG concentrations are positively correlated (McBeath et al., 1971; Naylor and Kronfeld, 1977; Calloway et al., 2002; Quigley et al., 2002; Foster et al., 2006). In the current study, increasing the IgG mass $(130 \mathrm{~L}, 160 \mathrm{~L}$, and $190 \mathrm{~L})$ resulted in a linear increase $(P<0.05)$ in the 24 -h serum IgG-to-serum total protein ratio (Table 2 and Figure 1). However, increasing doses of irradiation linearly reduced $(P<0.01)$ the 24 -h serum IgG-to-serum total protein ratio (Table 2 and Figure 2).

The results of the current study indicate that irradiation affects the AEA of IgG from bovine serum and that this effect may be dose related. The effects of irradiation are not clearly understood. These data suggest that irradiation affects the protein structure or functionality, resulting in a reduced AEA of IgG. Early studies of serum-based CR did not include an irradiation step in the production of the CR. In recent reports in which IgG isolated from bovine serum was not effective in preventing FPT, the serum-based CR used may have been irradiated at a high level. This could explain the increased incidence of 24-h serum IgG of less than 10 g/L (Swan et al., 2007). Based on the current study, results indicate that either a low irradiation dose or a greater mass of IgG was sufficient to reduce the incidence of FPT. If higher doses of irradiation are used, then a greater mass of IgG should be fed to reduce FPT.

\section{CONCLUSIONS}

A low dose of irradiation ( 3 to $7 \mathrm{kGy}$ ) did not reduce the AEA of IgG enough to increase the incidence of FPT in calves fed $130 \mathrm{~g}$ of IgG. A high irradiation dose (15 to $20 \mathrm{kGy}$ ) reduced 24 -h serum IgG, serum protein, and the AEA of IgG and increased the incidence of FPT. A greater mass of IgG fed to calves linearly increased the 24-h serum IgG and serum total protein, and decreased the AEA of IgG. Further studies are needed to determine the changes in IgG that occur with irradiation and the influence of the irradiation level on intestinal IgG absorption in the neonatal calf. In this study, CR isolated from bovine serum and receiving either no irradiation or a low level of irradiation, and providing 130 $\mathrm{g}$ of IgG in the first feeding, were sufficient to prevent FPT in at least $80 \%$ of the calves.

\section{REFERENCES}

Bender, E., J. Fritzsche, M. Bar, and W. Nordheim. 1989. The inactivation of mycoplasmas and bacteria in calf serum by 60 cobalt gamma rays. Arch. Exp. Vet. Med. 43:783-788.

Bovine Alliance on Management and Nutrition. 1995. A Guide to Colostrum and Colostrum Management for Dairy Calves. Am. Feed Ind. Assoc., Arlington, VA.

Calloway, C. D., J. W. Tyler, R. K. Tessman, and D. Hostetler. 2002. Comparison of refractometers and test endpoints in the measurement of serum protein concentration to assess passive transfer status in calves. J. Am. Vet. Med. Assoc. 221:1605-1608.

Carpenter, K.J. 1963. Measurement of the nutritive value of protein supplements. Page 104 in Recent Advancements in Food Science. Butterworths, London, UK.

Davis, C. L., and J. K. Drackley. 1998. The Development, Nutrition, and Management of the Young Calf. 1st ed. Iowa State University Press, Ames.

DeNise, S. K., J. D. Robison, G. H. Stott, and D. V. Armstrong. 1989. Effects of passive immunity on subsequent production in dairy heifers. J. Dairy Sci. 72:552-554. 
DeRouchey, J. M., M. D. Tokach, J. L. Nelssen, R. D. Goodband, S. S. Dritz, J. C. Woodworth, B. W. James, and D. E. Real. 2003. Effect of irradiation of individual feed ingredients and the complete diet on nursery pig performance. J. Anim. Sci. 81:1799-1805.

Donovan, G. A., I. R. Dohoo, D. M. Montgomery, and F. L. Bennett. 1998. Associations between passive immunity and morbidity and mortality in dairy heifers in Florida, USA. Prev. Vet. Med. 34:31-46.

El-Moneim, A., M. R. Afify, and M. A. Shousha. 1988. Effect of lowdose irradiation on soybean protein solubility, trypsin inhibitor activity, and protein patterns separated by polyacrylamide gel electrophoresis. J. Agric. Food Chem. 36:810-813.

Faber, S. N., N. E. Faber, T. C. McCauley, and R. L. Ax. 2005. Case study: Effects of colostrum ingestion on lactational performance. Profess. Anim. Sci. 21:420-425.

Farag, M. D. E. H. 1998. The nutritive value for chicks of full-fat soybeans irradiated at up to $60 \mathrm{kGy}$. Anim. Feed Sci. Technol. 73:319-328.

Ford, D. J. 1976. The effect of methods of sterilization on the nutritive value of protein in a commercial rat diet. Br. J. Nutr. 35:267-276.

Foster, D. M., G. W. Smith, T. R. Sanner, and G. V. Busso. 2006. Serum IgG and total protein concentrations in dairy calves fed two colostrum replacement products. J. Am. Vet. Med. Assoc. 229:1282-1285.

Garry, F. B., R. Adams, M. B. Cattell, and R. P. Dinsmore. 1996. Comparison of passive immunoglobulin transfer to dairy calves fed colostrum or commercially available colostral-supplement products. J. Am. Vet. Med. Assoc. 208:107-110.

Hammer, C. J., J. D. Quigley, L. Ribeiro, and H. D. Tyler. 2004. Characterization of a colostrum replacer and a colostrum supplement containing IgG concentrate and growth factors. J. Dairy Sci. 87:106-111.

Jones, C. M., R. E. James, J. D. Quigley III, and M. L. McGilliard. 2004. Influence of pooled colostrum or colostrum replacement on IgG and evaluation of animal plasma in milk replacer. J. Dairy Sci. 87:1806-1814

Leeson, S., and M. Marcotte. 1993. Irradiation of poultry feed. 2. Effect on nutrient composition. World's Poult. Sci. J. 49:120-131.

McBeath, D. G., W. J. Penhale, and E. F. Logan. 1971. An examination of the influence of husbandry on the plasma immunoglobulin level of the newborn calf, using a rapid refractometer test for assessing immunoglobulin content. Vet. Rec. 88:266-270.

McGuirk, S. M., and M. Collins. 2004. Managing the production, storage, and delivery of colostrum. Vet. Clin. North Am. Food Anim. Pract. 20:593-603.

Metta, V. C., and B. C. Johnson. 1959. Biological value of gamma irradiated corn protein and wheat gluten. J. Agric. Food Chem. $7: 131-133$
Morin, D. E., G. C. McCoy, and W. L. Hurley. 1997. Effects of quality, quantity, and timing of colostrum feeding and addition of a dried colostrum supplement in immunoglobulin G1 absorption in Holstein bull calves. J. Dairy Sci. 80:747-753.

National Animal Health Monitoring System. 1993. National dairy heifer evaluation project: Dairy herd management practices focusing on preweaned heifers. USDA-Animal and Plant Health Inspection Service-Veterinary Services, Ft. Collins, CO.

Naylor, J. M., and D. S. Kronfeld. 1977. Refractometry as a measure of the immunoglobulin status of the newborn dairy calf: Comparison with the zinc sulfate turbidity test and single radial immunodiffusion. Am. J. Vet. Res. 38:1331-1334.

Poulsen, K. P., V. Eggleston, M. T. Collins, and S. M. McGuirk. 2003. The efficacy of a colostrum replacement product used in dairy calves. Am. Coll. Vet. Intern. Med. (Abstr. 50)

Quigley, J. D., D. L. Fike, M. N. Egerton, J. J. Drewry, and J. D. Arthington. 1998. Effects of a colostrum replacement product derived from serum on immunoglobulin $\mathrm{G}$ absorption by calves. J. Dairy Sci. 81:1936-1939.

Quigley, J. D., C. J. Kost, and T. M. Wolfe. 2002. Absorption of protein and IgG in calves fed a colostrum supplement or replacer. J. Dairy Sci. 85:1243-1248.

Quigley, J. D., R. E. Strohbehn, C. J. Kost, and M. M. O'Brian. 2001. Formulation of colostrum supplements, colostrum replacer and acquisition of passive immunity in neonatal calves. J. Dairy Sci. 84:2059-2065.

Robison, J. D., G. H. Stott, and S. K. DeNise. 1988. Effects of passive immunity on growth and survival in the dairy heifer. J. Dairy Sci. 71:1283-1287.

Stott, G. H., D. B. Marx, B. E. Menefee, and G. T. Nightengale. 1979a. Colostral immunoglobulin transfer in calves. I. Period of absorption. J. Dairy Sci. 62:1632-1637.

Stott, G. H., D. B. Marx, B. E. Menefee, and G. T. Nightengale. 1979b. Colostral immunoglobulin transfer in calves. III. Amount of absorption. J. Dairy Sci. 62:1902-1907.

Swan, H., S. Godden, R. Bey, S. Wells, J. Fetrow, and H. ChesterJones. 2007. Passive transfer of immunoglobulin $\mathrm{G}$ and preweaning health in Holstein calves fed a commercial colostrum replacer. J. Dairy Sci. 90:3857-3866.

Tran, H., K. Marlowe, K. McKenney, G. Petrosian, Y. Griko, W. H. Burgess, W. N. Drohan, M. A. Imboden, D. Kempf, N. Boschetti, and D. M. Mann. 2004. Functional integrity of intravenous immunoglobulin following irradiation with a virucidal dose of gamma radiation. Biologicals 32:94-104.

Wittum, T. E., and L. J. Perino. 1995. Passive immune status at postpartum hour 24 and long-term health and performance of calves. Am. J. Vet. Res. 56:1149-1154. 